\title{
Stimulation of angiogenesis resulting from cooperation between macrophages and MDA- MB-231 breast cancer cells: proposed molecular mechanism and effect of tetrathiomolybdate
}

Ulrich Joimel $^{1 *}$, Caroline Gest ${ }^{1}$, Jeannette Soria ${ }^{2,3}$, Linda-Louise Pritchard ${ }^{4}$, Jérôme Alexandre ${ }^{2,5}$, Marc Laurent ${ }^{1}$, Emmanuel Blot ${ }^{1}$, Lionel Cazin ${ }^{1}$, Jean-Pierre Vannier ${ }^{1}$, Rémi Varin ${ }^{1}$, Hong $\mathrm{Li}^{1 \dagger}$, Claudine Soria ${ }^{1 \dagger}$

\begin{abstract}
Background: Infiltration by macrophages $(\mathrm{M} \phi)$ indicates a poor prognosis in breast cancers, in particular by inducing angiogenesis. Our study aimed 1) to investigate the mechanism by which cooperation between $\mathrm{M} \phi$ and aggressive breast cancer cells (MDA-MB-231) induces angiogenesis; 2) to examine the effect of tetrathiomolybdate (TM) on this angiogenic activity.

Methods: $M \phi$ coincubated with MDA-MB-231 were used as a model to mimic the inflammatory microenvironment. Angiogenesis induced by the culture media was tested in the chick chorioallantoic membrane (CAM). M $\phi$ phenotype was evaluated by 1) expression of the M1 marker CD80, and secretion of interleukin 10 (IL10), an M2 marker; 2) capacity to secrete Tumour Necrosis Factor $\alpha$ (TNF $\alpha$ ) when stimulated by lipopolysaccharide/ interferon $\gamma(\mathrm{LPS} / \mathrm{IFN} \gamma) ; 3)$ ability to induce MDA-MB-231 apoptosis. To explore the molecular mechanisms involved, cytokine profiles of conditioned media from MDA-MB-231, M $\phi$ and the coculture were characterised by an antibody cytokine array. All experiments were carried out both in presence and in absence of TM.

Results: Incubation of M $\phi$ with MDA-MB-231 induced a pro-angiogenic effect in the CAM. It emerged that the angiogenic activity of the coculture is due to the capacity of $M \phi$ to switch from $M 1 M \phi$ towards $M 2$, probably due to an increase in Macrophage Colony Stimulating Factor. This M1-M2 switch was shown by a decreased expression of CD80 upon LPS/IFN $\gamma$ stimulation, an increased secretion of IL-10, a decreased secretion of TNF $\alpha$ in response to LPS/IFN $\gamma$ and an inability to potentiate apoptosis. At the molecular level, the angiogenic activity of the coculture medium can be explained by the secretion of CXC chemokines/ELR ${ }^{+}$and CC chemokines. Although TM did not modify either the M2 phenotype in the coculture or the profile of the secreted chemokines, it did decrease the angiogenic activity of the coculture medium, suggesting that TM inhibited angiogenic activity by interfering with the endothelial cell signalling induced by these chemokines.
\end{abstract}

Conclusions: Cooperation between M $\phi$ and MDA-MB-231 transformed M1 M $\phi$ to an angiogenic, M2 phenotype, attested by secretion of CXC chemokines/ELR ${ }^{+}$and CC chemokines. TM inhibited this coculture-induced increase in angiogenic activity, without affecting either $\mathrm{M} \phi$ phenotype or cytokine secretion profiles.

\footnotetext{
* Correspondence: ulrich.joimel@gmail.com

† Contributed equally

${ }^{1}$ Laboratoire M.E.R.C.I - EA 3829, Faculté de Médecine et de Pharmacie,

Université de Rouen, 22 Bd Gambetta, 76183 Rouen cedex, France
} 


\section{Background}

It has become clear that analysis of tumour stroma is of crucial importance to better understanding cancer progression. Cancer cell growth and invasion of surrounding tissues, as well as the metastatic process itself, require the support of the cancer stroma.

Macrophages $(\mathrm{M} \phi)$ form the major component of the inflammatory infiltrate observed in tumours [1]. They exhibit a distinct phenotype and are termed TumourAssociated Macrophages (TAM) [2]. Monocytes enter tumours through blood vessels, and a number of tumour-derived chemoattractants are thought to ensure this ongoing recruitment $[3,4]$. This is also supported by the observation that the levels of chemoattractant proteins in tumours correlate positively with the numbers of TAMs present in these tumours [5]. Classically, it has been accepted that fully activated $\mathrm{M} \phi$ have the potential to inhibit tumour development. TAMs that express an M1 phenotype are characterized by a proinflammatory cytokine profile and expression of Major Histocompatibility Complex molecules. They are capable of killing tumour cells mainly by secreting inflammatory cytokines such as Tumour Necrosis Factor $\alpha(\mathrm{TNF} \alpha)$. Although associated with better prognosis, immune responses to a tumour are often weak and not able to destroy the tumour completely [6], suggesting that tumours have developed mechanisms for escaping immune surveillance. Further, the presence of $\mathrm{M} \phi$ in breast cancer is associated with a poor prognosis [7-10] due to the role of TAMs as promoters of tumour progression and invasion. Increasing evidence also indicates that TAMs enhance angiogenesis, contributing to cancer cell proliferation and dissemination [11-14]. This could explain the positive relationship between high levels of TAMs and breast cancer aggressiveness and their correlation with high vessel density as reported in the literature $[15,16]$.

We have previously shown that the deleterious role of $\mathrm{M} \phi$ in cancer progression is due to the cooperation of monocytes with cancer cells [17]. The modifications of $\mathrm{M} \phi$ functions in tumours could be explained by a switch of M1 M $\phi$ to M2 M $\phi$, which have protumoral properties, including promotion of angiogenesis, matrix remodelling and suppression of adaptive immunity $[18,19]$. This indicates a functional plasticity and an in situ $\mathrm{M} \phi$ reprogramming. The biological mechanism for this switch remains controversial. For Hagemann et al. [20,21] and Greten et al. [22], the malignant epithelial cancer cells drive nuclear factor kappa-light-chainenhancer of activated B cells (NF- $\kappa \mathrm{B}$ ) activation by TAMs in a way that maintains their immunosuppressive M2 phenotype. Consequently, the blockage of NF- $\kappa \mathrm{B}$ might be expected to switch the M2 M $\phi$ to an M1 phe- notype. Hence these studies would predict a potential anti-tumour effect of NF- $\kappa$ B inhibitors by the restoration of M1 immunity, providing a cytotoxic activity. However, the role of NF- $\kappa \mathrm{B}$ in this switch is contested by others. Saccani et al. [23] and Bohuslav J et al. [24] conversely proposed that during the M1 to M2 M $\phi$ switch, an inactivation of NF- $\kappa \mathrm{B}$ occurs, explaining the absence of TNF $\alpha$ production when $\mathrm{M} \phi$ are stimulated by lipopolysaccharide (LPS). This could be due to a massive nuclear localization of the p50 NF- $\kappa \mathrm{B}$ protein resulting in p50/p50 homodimers. Since the p50 homodimers lack the transactivation domain, they compete with the canonical $\mathrm{p} 65 / \mathrm{p} 50$ heterodimers for the NF- $\kappa \mathrm{B}$ binding sites on the inflammatory gene promoters, thereby blocking $\mathrm{p} 65 / \mathrm{p} 50$ promoter binding and gene transcription.

Thus, although the relationship between inflammation and cancer aggressivity is widely accepted, many of the molecular and cellular mechanisms mediating this relationship remain unclear. The current study was designed to determine the role of the cooperation between $\mathrm{M} \phi$ and the aggressive breast cancer cells MDA-MB-231 in angiogenesis promotion. To elucidate the mechanism, we mimicked the inflammatory tumour environment by a coincubation of MDA-MB-231 cells with $\mathrm{M} \phi$. Angiogenic activity of the coculture medium was compared with the culture medium from both MDA-MB-231 and M $\phi$ cultured individually in the chick chorioallantoic membrane (CAM) model.

We first determined that the cooperation between $\mathrm{M} \phi$ and cancer cells led to a switch of M1 M $\phi$ to the M2 phenotype, known to be angiogenic. Then we explored the potential molecular mechanisms responsible for this angiogenic activity. Results indicate that a wide repertoire of chemokines (CXC-ELR ${ }^{+}$and CC-chemokines) may drive the neoangiogenesis induced by the cooperative effects of cancer cells and $\mathrm{M} \phi$. Finally, tetrathiomolybdate (TM), an oral copper-depleting agent that has been shown to inhibit tumour-cell-induced angiogenesis [25-27] was tested in our model of cooperation between $\mathrm{M} \phi$ and MDA-MB-231. This was important to check because the effect of TM has not previously been analysed in this context of inflammation in cancers.

\section{Methods}

\section{Cell Culture and Reagents}

MDA-MB-231 cells were maintained in RPMI 1640 medium (Eurobio) supplemented with $100 \mathrm{U} / \mathrm{ml}$ penicillin (Eurobio), $100 \mu \mathrm{g} / \mathrm{ml}$ streptomycin (Eurobio), $2 \mathrm{mM}$ L-glutamine (Eurobio) and 10\% heat-inactivated foetal calf serum (FCS, Eurobio). All incubations were carried out in a humidified atmosphere at $37^{\circ} \mathrm{C}$ and $5 \% \mathrm{CO}_{2}$. LPS was purchased from Sigma-Aldrich and human 
recombinant interferon $\gamma($ IFN $\gamma)$ from $R \& D$ Systems. TM is a gift from Professor F. Sécheresse, Institut Lavoisier (CNRS UMR 8637, Versailles).

\section{Preparation of $\mathbf{M} \phi$}

Human monocytes were isolated as described [28]. Briefly, monocytes were isolated from buffy coats using lymphocyte separation medium (Eurobio). Peripheral blood mononuclear cells were washed three times with phosphate-buffered saline (PBS, Eurobio) and allowed to adhere to Primaria ${ }^{\mathrm{TM}}$ cell culture flasks (Becton Dickinson) for $1 \mathrm{~h}$ at $37^{\circ} \mathrm{C}$. Nonadherent cells were removed. Monocytes were then incubated in AIM-V ${ }^{\circledR}$ medium (Gibco) for 7 days, as recommended for longterm cultivation of human $\mathrm{M} \phi$ [29]. Medium was changed, and nonadherent cells discarded, every 2 days. We found that all monocyte-derived cells isolated this way express the marker CD14, which can be used to distinguish them from cancer cells.

\section{Coculture of MDA-MB-231 cancer cells with $\mathbf{M} \phi$}

Primary human monocyte-derived $\mathrm{M} \phi$ were detached using a 30 min incubation with Accutase ${ }^{\mathrm{TM}}$ enzyme cell detachment medium (eBioscience). $25 \times 10^{3}$ MDA-MB231 cells were plated in 96-well culture dishes $\left(7.8 \times 10^{4}\right.$ cells $/ \mathrm{cm}^{2}$ ) and allowed to adhere for $6 \mathrm{~h}$ at $37^{\circ} \mathrm{C}$. More than $95 \%$ of the cells adhered to the wells. Then the same number of $\mathrm{M} \phi$ was added, and cocultures were maintained for 5 days in RPMI 1640 medium supplemented with $100 \mathrm{U} / \mathrm{ml}$ penicillin, $100 \mu \mathrm{g} / \mathrm{ml}$ streptomycin, $2 \mathrm{mM}$ L-glutamine and 10\% heat-inactivated FCS. Spent medium was replaced by fresh medium every $24 \mathrm{~h}$. Control groups consisted of $2.5 \times 10^{4}$ MDA-MB-231 alone and of $2.5 \times 10^{4} \mathrm{M} \phi$ alone cultured under the same conditions. Where indicated, after 5 days of incubation the cultures were treated with $1 \mu \mathrm{g} / \mathrm{ml}$ LPS and $5 \mathrm{ng} / \mathrm{ml}$ IFN $\gamma$ for $24 \mathrm{~h}$ to activate the $\mathrm{M} \phi$. Cultures approached but did not reach confluence during this time.

\section{In vivo angiogenesis assays using the CAM model}

All MDA-MB-231 and M $\phi$ cultures were carried out both in presence and in absence of $5 \mu \mathrm{M}$ TM (final concentration). The CAM assay was performed as described by others [30], using conditioned media collected from the cocultures and from individual MDA-MB-231 and $\mathrm{M} \phi$ cultures during the final $24 \mathrm{~h}$ of incubation, and stored at $-80^{\circ} \mathrm{C}$ until use. Briefly, fertilized chick eggs (White Leghorn) purchased from the Ferme Avicole HAAS, Kaltenhouse, France, were incubated for 4 days at $37^{\circ} \mathrm{C}$ and a relative humidity of $80 \%$. During this period, the eggs were positioned with the pointed end down and rotated several times. After this incubation, the shells were cracked open and the embryo eggs placed in plastic culture dishes (Merck-Eurolab) according to an established shell-less culture technique exposing the CAM to a direct access for experimental manipulation. At day 6 of embryonic development, angiogenic areas were circled with a silicon ring (Weber Métaux). To induce angiogenesis, $33 \mu \mathrm{l}$ of either the culture medium to be tested or recombinant human basic Fibroblast Growth Factor (bFGF) (R\&D Systems) (positive control) were next placed inside the rings on successive days for 3 days. Treated areas were photographed and the extent of angiogenesis evaluated $24 \mathrm{~h}$ after the last treatment: the total number of vessels which had sprouted from the primary vessels of the CAM and the total length of the neoangiogenesis were determined using Saisam software (Microvision Instruments).

\section{Characterization of $\mathbf{M} \phi$ by immunofluorescence analysis}

Cultures and cocultures were carried out as described above, except that each cell population was seeded into 8-well Lab-Tek ${ }^{\mathrm{TM}}$ II $-\mathrm{CC} 2^{\mathrm{TM}}$ chambers (Nunc) at a density of $5.7 \times 10^{4}$ cells $/ \mathrm{cm}^{2}$. Five days later, all cultures were treated with $1 \mu \mathrm{g} / \mathrm{ml} \mathrm{LPS}$ and $5 \mathrm{ng} / \mathrm{ml} \mathrm{IFN} \gamma$ for $24 \mathrm{~h}$ before washing and labelling. $\mathrm{M} \phi$ were identified by examining the expression of CD14, which is a differentiation antigen expressed by monocytes and $\mathrm{M} \phi$, and of CD80, which is a marker of M1 M $\phi$ [31]. Expression of these molecules was evaluated by immunofluorescence both before and after activation with $1 \mu \mathrm{g} / \mathrm{ml}$ LPS and $5 \mathrm{ng} / \mathrm{ml} \mathrm{IFN} \gamma$ for $24 \mathrm{~h}$. Breast cancer cells were identified by cytokeratin 19 (CK 19) expression.

Briefly, cells were fixed for $15 \mathrm{~min}$ in $4 \%$ paraformaldehyde/PBS, then washed and incubated for 30 minutes with PBS containing $5 \%$ bovine serum albumin (BSA). For $\mathrm{M} \phi$ identification, samples were incubated with rabbit anti-CD14 polyclonal antibodies at $2 \mu \mathrm{g} / \mathrm{ml}$ (Abcam) or biotinylated monoclonal anti-human CD80 at $2.5 \mu \mathrm{g} / \mathrm{ml}$ (Ancell Corporation) for $60 \mathrm{~min}$ at room temperature. For identification of breast cancer cells, they were then washed in $\mathrm{PBS} / 1 \% \mathrm{BSA}$ before incubation with monoclonal antihuman CK 19 (Dako) diluted 1:50 in PBS/1\% BSA. Following washing in PBS with $1 \%$ BSA, cells were incubated with, respectively, DyLight $488^{\mathrm{TM}}$-conjugated goat anti-rabbit IgG secondary antibody or DyLight $549^{\mathrm{TM}}$-conjugated streptavidin (Thermoscientific) for 60 minutes at room temperature or else Texas-Red labelled goat anti-mouse Ig diluted 1:2000 (AbD Serotec). After final washing, cover slips were mounted with mounting medium (Immunoconcepts). Samples were photographed using a Leica DM 5500B. Controls prepared without primary antibodies confirmed that, under the conditions used, background fluorescence was negligible.

\section{Ability of LPS + IFN $\gamma$-activated $\mathrm{M} \phi$ to secrete TNF $\alpha$}

For these experiments, cells cultured as described above were activated on day 5 with $1 \mu \mathrm{g} / \mathrm{ml} \mathrm{LPS} \mathrm{and} 5 \mathrm{ng} / \mathrm{ml}$ 
IFN $\gamma$ for $24 \mathrm{~h}$. These 24 -h culture supernatants were then collected and tested for TNF $\alpha$. Concentrations of TNF $\alpha$ within the supernatants were determined by human TNFa Enzyme-Linked Immunosorbent Assay (ELISA) Ready-Set-go! (eBioscience) using the standard protocol given by the manufacturer, and compared to those of supernatants from non-activated control cultures. TNF $\alpha$ concentrations are expressed in $\mathrm{pg} / \mathrm{ml} .3$ independent experiments were carried out both in presence and in absence of $5 \mu \mathrm{M}$ TM.

\section{Ability of $\mathbf{M} \phi$ to induce apoptosis in cocultures}

$\mathrm{M} \phi$ and MDA-MB-231 cells were cultured separately and together (coculture) as indicated above for 5 days, in presence or absence of $5 \mu \mathrm{M}$ TM. Apoptosis was measured using the ELISAPLUS cell death detection kit (Roche Diagnostics). Briefly, apoptosis-induced DesoxyRibonucleic Acid (DNA) fragmentation was evaluated by quantifying the histone-complexed DNA fragments (nucleosomes) found in the cytoplasm, as indicated by the manufacturer. Results are expressed as the adjusted absorbance, A405 minus A490.

\section{Ability of $\mathbf{M} \phi$ to secrete interleukin 10 (IL-10)}

For these experiments, supernatants were harvested on day 5 from cells cultured as described above. These 24-h culture supernatants were then tested for IL-10. Concentrations of IL-10 within the supernatants were determined by human IL-10 ELISA Ready-Set-go! (eBioscience) using the standard protocol given by the manufacturer. IL-10 concentrations are expressed in $\mathrm{pg} / \mathrm{ml} .3$ independent experiments were carried out both in presence and in absence of $5 \mu \mathrm{M}$ TM.

\section{Cytokine array}

The Human Cytokine Antibody Array III kit (RayBiotech) was used to evaluate 42 different cytokines: Epithelial Neutrophil-Activating peptide-78 (ENA-78), Granulocyte Colony-Stimulating Factor (GCSF), Granulocyte-Macrophage Colony Stimulating Factor (GM-

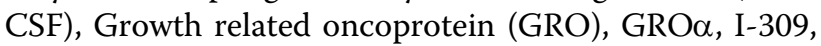
IL-1 $\alpha$, IL-1 $\beta$, IL-2, IL-3, IL-4, IL-5, IL-6, IL-7, IL-8, IL-10, IL-12 p40p70, IL-13, IL-15, IFN $\gamma$, Monocyte Chemotactic Protein-1 (MCP-1), MCP-2, MCP-3, Macrophage Colony Stimulating Factor (MCSF), MacrophageDerived Chemokine (MDC), Monokine induced by IFN $\gamma$ (MIG), Macrophage Inflammatory Protein-1 $\alpha$ (MIP-1 $\alpha$ ), Regulated on Activation Normal T cell Expressed and Secreted (RANTES), human Stem Cell Factor (SCF), Stromal-Derived Factor-1 (SDF-1), Thymus and Activation-Regulated Chemokine (TARC), Transforming Growth Factor- $\beta 1$ (TGF- $\beta 1$ ), TNF $\alpha$, TNF- $\beta$, Epidermal Growth Factor (EGF), Insulin-like Growth Factor-I (IGF-I), Angiogenin, Oncostatin M, Thrombopoietin,
Vascular Endothelial Growth Factor (VEGF), PlateletDerived Growth Factor-BB (PDGF BB) and Leptin. GRO detects CXC Ligand 1 (CXCL1), CXCL2 and CXCL3; GRO $\alpha$ detects only CXCL1. VEGF detects VEGF-165 and VEGF-121.

Briefly, $1 \mathrm{ml}$ of undiluted supernatants harvested on day 5 from cells cultured as described above were incubated with arrayed antibody membranes, which were then exposed to the specific biotin-antibody cocktail, following the manufacturer's instructions. Signals were detected using labelled streptavidin by exposure on $\mathrm{X}$ ray films. The relative amount of each cytokine present in the coculture medium is presented as the fold increase of the spot intensity in the coculture medium as compared to that of the culture medium of either $\mathrm{M} \phi$ cultured alone (for cytokines which were not secreted by MDA-MB-231), or MDA-MB-231 cultured alone (for cytokines which were not secreted by $\mathrm{M} \phi$ ), or else the sum of the two (for cytokines secreted separately by both $\mathrm{M} \phi$ and MDA-MB-231 when cultured individually). The area density of the spots was evaluated using imageJ (written in Java) which was downloaded from the National Centre for Biotechnology Information. Signals were normalized against the positive controls across membranes. Cytokine array experiments were carried out in duplicate.

\section{Results}

Angiogenic activity of the M $\phi+$ MDA-MB-231 coculture medium in the CAM

We found that the conditioned medium from cocultures of $\mathrm{M} \phi+\mathrm{MDA}-\mathrm{MB}-231$ induced a more potent angiogenic response in the CAM than that induced by conditioned medium from either $\mathrm{M} \phi$ or MDA-MB-231 cells cultured alone, as shown by the formation of a secondary dense thin capillary network only after treatment with coculture medium (Figure 1A). Indeed, both the number and the cumulative length of the capillaries that sprouted from CAM vessels were significantly increased by the coculture medium (Figure $1-\mathrm{B})(\mathrm{p}<0.05)$. The positive control was bFGF.

Cell densities on day 0 and after 5 days of culture (day 5) When plating the cells on day 0 , more than $95 \%$ were adherent (both cancer cells and $\mathrm{M} \phi$ ). We next determined the relative proportions of the two cell types in the coculture after 5 days, because MDA-MB-231 is a cell line which proliferates in culture, whereas $\mathrm{M} \phi$, which are primary cells, do not. We found that in 5 days the number of MDA-MB-231 increased 5.3-fold (standard error of the mean (SEM), \pm 0.35) (not shown). In contrast, $\mathrm{M} \phi$ numbers did not change during the 5 days of incubation, and fewer than $10 \%$ were found detached, floating in the supernatants. After the 


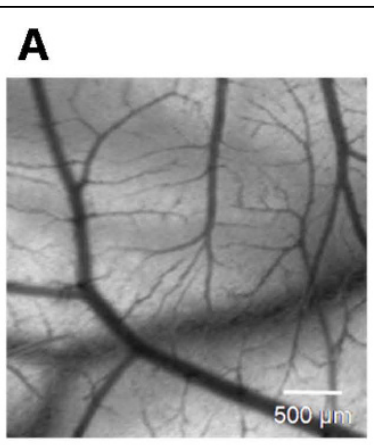

MDA-MB-231

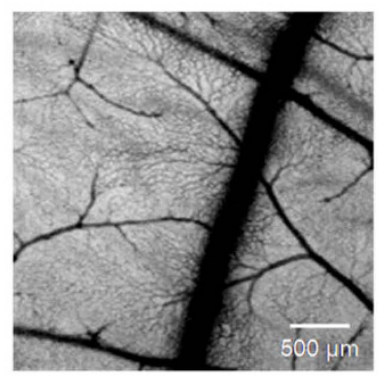

Coculture

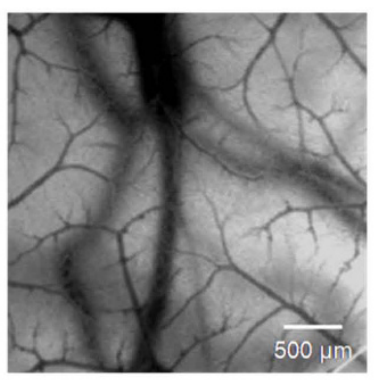

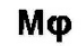

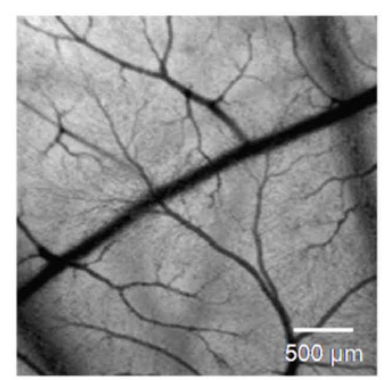

bFGF $25 \mathrm{ng} / \mathrm{ml}$

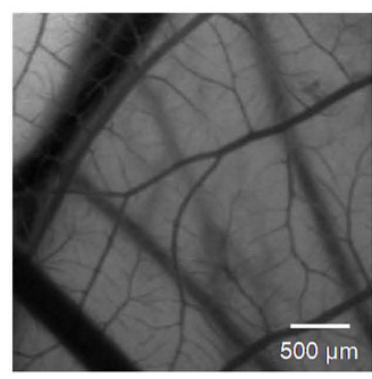

Coculture +TM

B
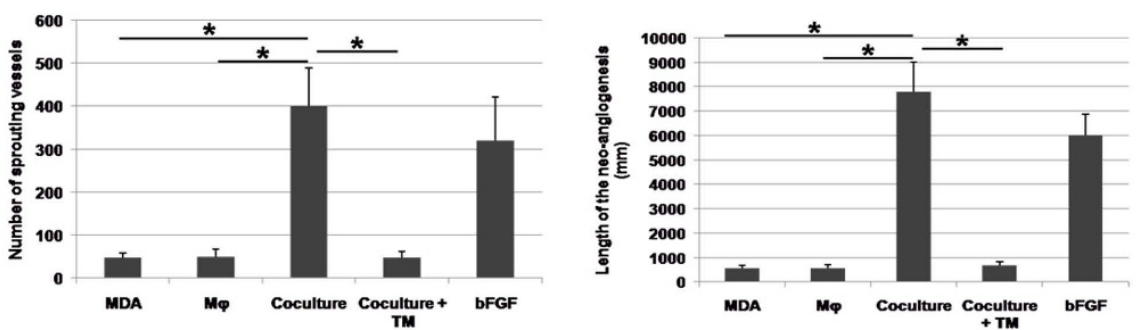

Figure 1 Effect of the cooperation between $\mathbf{M} \phi$ and MDA-MB-231 cells on vascularisation of the CAM. MDA-MB-231 cells were seeded at a density of $7.8 \times 10^{4}$ cells $/ \mathrm{cm}^{2}$, with (coculture) or without the same number of $\mathrm{M} \phi$. Spent medium was replaced by fresh medium every day. After 5 days of incubation, the conditioned media corresponding to the final $24 \mathrm{~h}$ of culture were tested for their angiogenic activity as follows: each day, for 3 days, $33 \mu \mathrm{L}$ of these media were introduced into silicon rings placed on CAMs from 6-day-old chick embryos. bFGF (25 ng/ml) was used as positive control. Panel A: Treated areas were photographed $24 \mathrm{~h}$ after the last treatment. Note the increase in the CAM of a denser secondary capillary network induced by the coculture medium, in comparison to that induced by conditioned medium from either MDA-MB-231 or M $\phi$ cultured alone. This secondary capillary network was inhibited by the addition of $5 \mu \mathrm{M}$ TM during the coculture. Panel $\mathbf{B}$ : total number of vessels that sprouted from the primary vessels of the CAM and total length of the neoangiogenesis. Mean of 3 independent experiments \pm SEM . ${ }^{*} p<0.05$, Mann-Whitney $U$ test.

5 days of coculture, the ratio of CK $19^{+}$(cancer cells) to $\mathrm{M} \phi$ was also determined. It was found that $15 \%$ of the cells were $\mathrm{M} \phi$, and 85\% MDA-MB-231 (not shown).

\section{Modifications of $\mathbf{M} \phi$ phenotype induced by coculture}

Because the switch of M1 M $\phi$ to the M2 phenotype is known to induce angiogenesis, we investigated the possibility of an M1-M2 switch when $\mathrm{M} \phi$ were coincubated with MDA-MB-231 cells. Immunolabelling of $\mathrm{M} \phi$ cultured in presence or absence of MDA-MB-231 showed that all cells isolated as $\mathrm{M} \phi$ are CD14 positive. These $\mathrm{CD} 14^{+}$cells were found to express CD80 only when activated by LPS/IFN $\gamma$, indicating that activation could stimulate them to differentiate towards an M1 phenotype. However, in the cocultures of $\mathrm{M} \phi$ with MDAMB-231 cells, expression of CD80 by these activated $\mathrm{M} \phi$ was lost (Figure 2). 


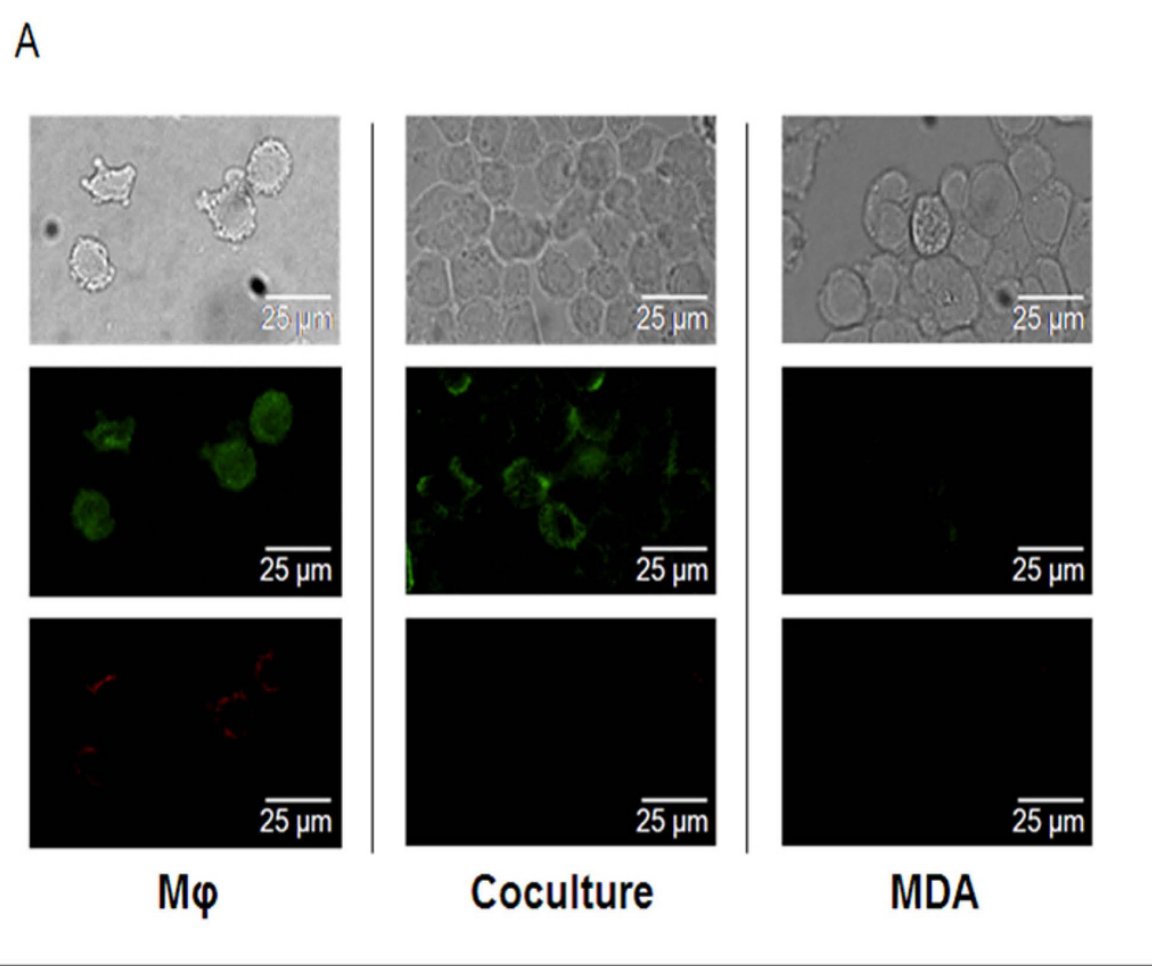

B
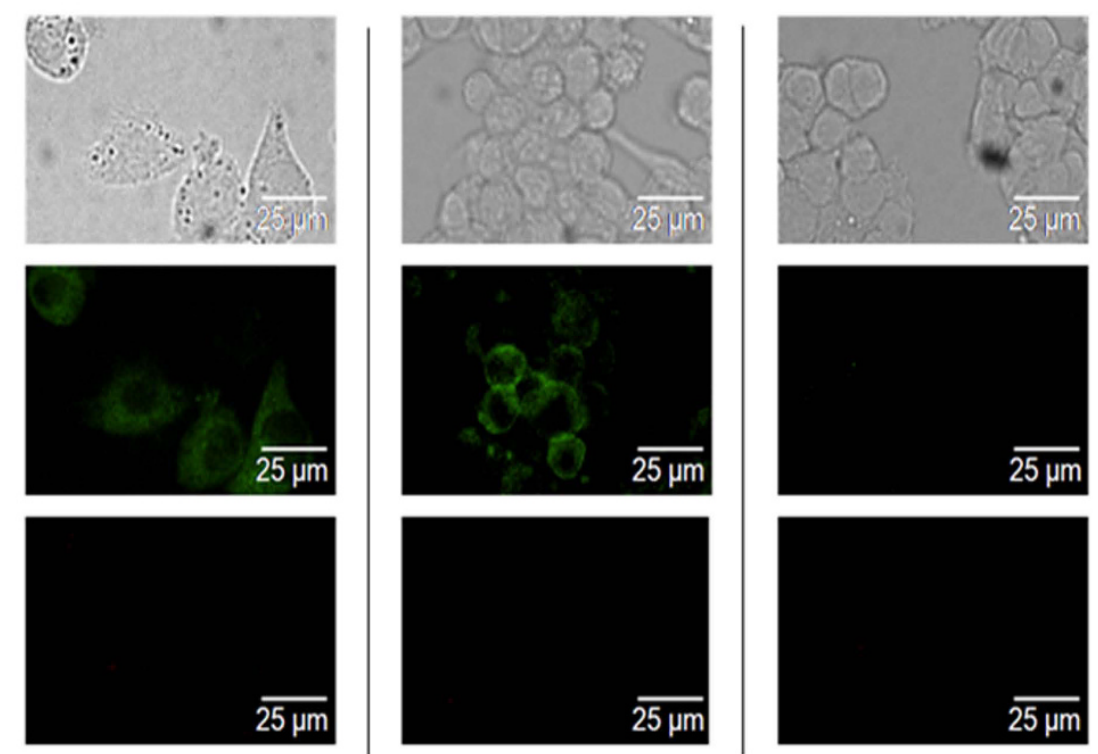

$\mathrm{M \varphi}$

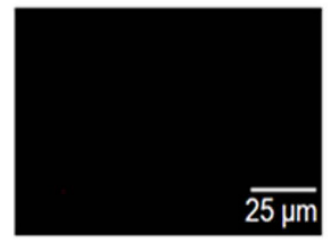

Coculture

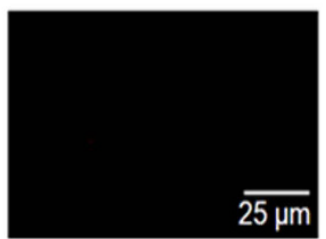

MDA

Figure $\mathbf{2}$ Immunolabelling of $\mathbf{M} \phi$ by the monocyte/M $\phi$ marker CD14 and the $\mathbf{M} 1 \mathbf{M} \phi$ marker CD80. M $\phi$ were seeded at a density of $5.7 \times$ $10^{4}$ cells $/ \mathrm{cm}^{2}$, with (coculture) or without the same number of MDA-MB-231 cells. In each case, the culture medium was replaced daily. 5 days later, all cultures were treated with $1 \mu \mathrm{g} / \mathrm{ml}$ LPS and $5 \mathrm{ng} / \mathrm{ml} \mathrm{IFN \gamma}$ for $24 \mathrm{~h}$ before washing and labelling. CD14 fluorescent labelling is green, CD80 is red. Panel A: without TM, it can be seen that CD80 was expressed on activated M $\phi$ cultured alone and was not detectable on M $\phi$ in the cocultures. Panel B: in presence of TM, no CD80-positive cells were found in any of the cultures. 


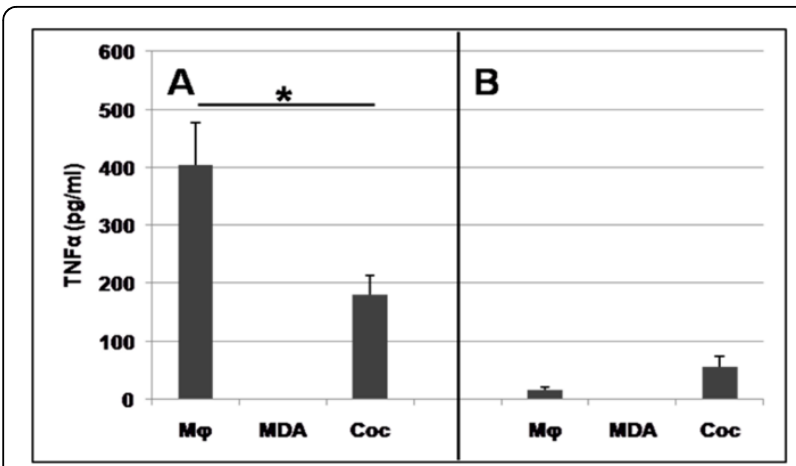

Figure 3 Secretion of TNF $\alpha$ into the culture medium of LPS and IFN $\gamma$-treated M $\phi$, MDA-MB-231 and cocultures. Cultures were incubated in the absence $(\mathbf{A})$ or presence $(\mathbf{B})$ of $5 \mu \mathrm{M}$ TM, the corresponding medium being renewed daily. In all cases, cells were stimulated on day 5 with $1 \mu \mathrm{g} / \mathrm{ml}$ LPS and $5 \mathrm{ng} / \mathrm{ml} \mathrm{IFN \gamma}$ for $24 \mathrm{~h}$. Supernatants from these stimulated M $\phi$, MDA-MB-231 and cocultures were then tested for the presence of TNF $\alpha$ by ELISA. Mean \pm SEM of 3 independent experiments. ${ }^{*} p<0.05$ between $M \phi$ and coculture without TM; $p<0.01$ between $M \phi$ without TM and $\mathrm{M} \phi$ with TM; $\mathrm{p}<0.05$ between coculture without and with TM. Mann-Whitney test. TNF $\alpha$ was not detected in the supernatants of non-activated cells, as also observed by cytokine array.

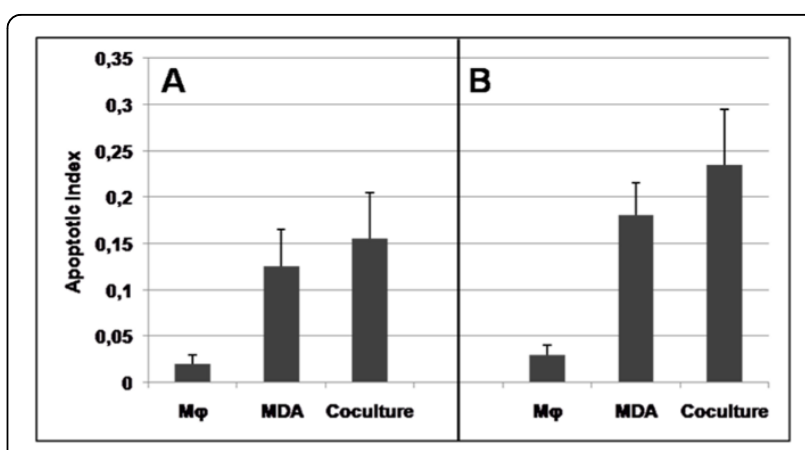

Figure 4 Apoptosis of $\mathbf{M} \phi$, MDA-MB-231 breast cancer cells, and coculture cells. Cells were incubated for 5 days in the absence (A) or presence (B) of TM (5 $\mu \mathrm{M}$, final concentration), the corresponding medium being renewed daily. Cell Death Detection ELISA PLUS enzyme immunoassay (Roche Applied Science) was used for the quantitative in vitro determination of cytoplasmic histone-associated DNA fragments (mono- and oligonucleosomes) in the cytoplasmic fractions of cells from these 5-day cultures. The results are expressed as the absorbance at $405 \mathrm{~nm}$ minus the absorbance at $492 \mathrm{~nm}$. The apoptosis index measured in the coculture was equivalent to the sum of the index measured in cultures of MDA-MB-231 alone plus that of M $\phi$ alone. Mean \pm SEM of 3 independent experiments.
Effects of coculture on apoptotic activity, TNF $\alpha$ and IL-10 secretion

Without stimulation, $\mathrm{M} \phi$ did not secrete detectable amounts of TNF $\alpha$. In contrast, as shown in Figure 3, panel $\mathrm{A}, \mathrm{M} \phi$ activated by LPS/IFN $\gamma$ secreted a large amount of TNF $\alpha$. However, when these $\mathrm{M} \phi$ were cocultured with MDA-MB-231, a decreased secretion of TNF $\alpha$ was observed $(180 \mathrm{pg} / \mathrm{ml}$ in the coculture medium versus $400 \mathrm{pg} / \mathrm{ml}$ in the $\mathrm{M} \phi$ culture). This reduction of TNF $\alpha$ secretion by activated $\mathrm{M} \phi$ is indicative of a change in $\mathrm{M} \phi$ phenotype from M1 to M2.

We also found that the coculture of $\mathrm{M} \phi$ with cancer cells did not potentiate the apoptotic activity of the $\mathrm{M} \phi$. Indeed, as shown in Figure 4, panel A, the apoptosis index measured in the coculture was equivalent to the sum of the index measured in cultures of MDA-MB-231 alone plus that of $\mathrm{M} \phi$ alone.

All these results suggest that $\mathrm{M} \phi$ incubated with MDA-MB 231 lose their M1 phenotype. Furthermore, a switch toward the M2 phenotype is suggested by the cooperation of $\mathrm{M} \phi$ with MDA-MB-231, because the secretion of IL-10 increased approximately twofold in the coculture medium, compared to medium from $\mathrm{M} \phi$ cultured alone (Figure 5).

\section{Molecular mechanism underlying the angiogenic activity induced by the coculture medium}

To explore the molecular mechanism responsible for the angiogenic activity that arises from the cooperation between $\mathrm{M} \phi$ and cancer cells, we used an antibody- cytokine array to analyse the secretion of cytokines and chemokines. Results of this analysis (shown in Figure 6 and Table 1) revealed an increase in the coculture medium, in comparison to the conditioned medium of both $\mathrm{M} \phi$ alone and MDA-MB-231 alone, of the following mediators: CXC chemokines with an ELR motif, chemokines that are known to be angiogenic (such as GRO, GRO $\alpha$, ENA-78 and IL-8) and chemoattractant chemokines, such as MCP-1 and MCP-3, that can lead to a

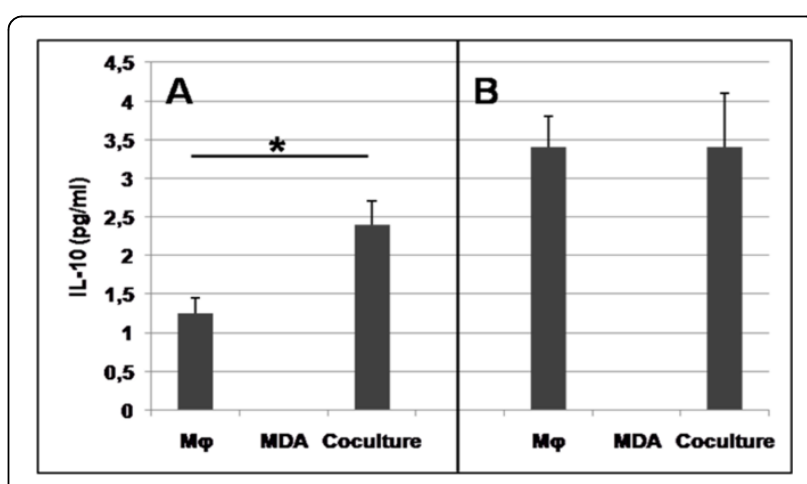

Figure 5 IL-10 secretion by $\mathbf{M} \phi$ cultured in the absence or presence of MDA-MB-231. Cells were incubated for 5 days in the absence $(\mathbf{A})$ or presence $(\mathbf{B})$ of TM (5 $\mu \mathrm{M}$, final concentration), the corresponding medium being renewed daily; then culture media corresponding to the final $24 \mathrm{~h}$ of incubation were tested for IL-10 by ELISA. No IL-10 was detected in medium from MDA-MB-231 cultured alone. Mean \pm SEM of 3 independent experiments. ${ }^{*} p<$ 0.05 between $\mathrm{M} \phi$ without TM and coculture without TM; $\mathrm{p}<0.05$ between $\mathrm{M} \phi$ without TM and $\mathrm{M} \phi$ with TM. 

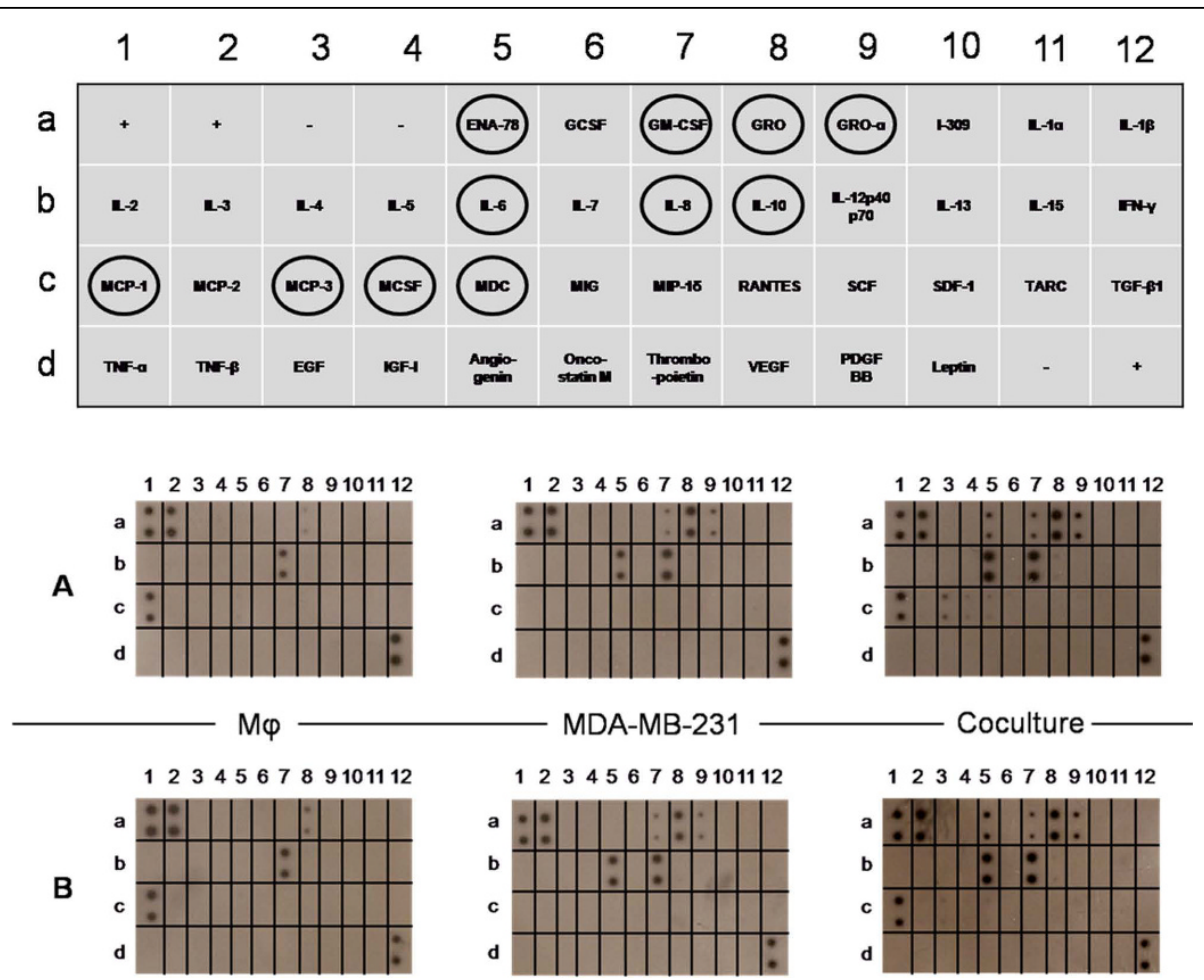

Figure 6 Cytokines secreted by $\mathbf{M} \phi$, by MDA-MB-231 cells and by the coculture. The assay was performed after 5 days of culture in the absence $(\mathbf{A})$ or presence (B) of $5 \mu \mathrm{M}$ TM (final concentration), the corresponding medium being renewed daily. Culture supernatants corresponding to the final $24 \mathrm{~h}$ of incubation were then collected and assayed for cytokine production using the Human Cytokine Antibody Array III kit (RayBiotech). Ellipses indicate the coordinates of the secreted cytokines and chemokines. Films were developed from array membranes following incubation with supernatants from either $\mathrm{M} \phi$ cultures, MDA-MB-231 cells or the coculture. Positive controls are located at positions A1, A2, D12. Negative controls are located at positions A3, A4 and D11. This experiment was repeated once with similar results.

positive feed-back. An increased secretion of M-CSF was also found and could be responsible for the switch from M1 to M2. Fold changes of cytokine levels in the coculture medium as compared to culture medium of $\mathrm{M} \phi$, MDA-MB-231 or the sum of M $\phi+$ MDA-MB-231 cultured separately are presented in Table 2 .

A faint spot indicating a low level of IL-10 production was also observed in the coculture medium, which corroborates the ELISA results suggesting that $\mathrm{M} \phi$ in the coculture acquired the M2 phenotype.

\section{Effect of TM on the angiogenic activity induced by the coculture}

As shown in Figure 1, panels A and B, TM inhibited the angiogenesis that was induced in the CAM by the coculture medium: both the total number of sprouting vessels and the cumulative length of those vessels induced by TM-containing coculture medium were similar to those measured with conditioned medium from either monocytes or MDA-MB-231 cells cultured separately in the absence of TM. The observed difference in the effects of coculturing the cells in presence versus absence of TM is highly significant.
We next analysed the mechanism by which TM inhibited the angiogenic activity of the coculture medium. Because the M2 M $\phi$ phenotype was found to be causally implicated in the angiogenic activity of the coculture medium, we first hypothesized that TM should be able to inhibit the M1-M2 switch observed during the coculture. However, TM did not elicit a change from M2 to M1 phenotype, as shown by the following results: 1 ) in the coculture medium, whether in the absence or in the presence of TM, CD14+ M $\phi$ activated by LPS/IFN $\gamma$ failed to express CD80; and what's more, the expression of $\mathrm{CD} 80$ on $\mathrm{M} \phi$ cultured alone was prevented by the addition of TM to the culture medium, as shown in Figure 2A and 2B. 2) TM inhibited by $80 \%$ the secretion of TNF $\alpha$ in LPS/IFN $\gamma$ stimulated $\mathrm{M} \phi$ cultured either alone or with MDAMB-231, suggestive of an M2 phenotype (Figure 3). Likewise, TM did not potentiate the apoptotic activity in the coculture, where the apoptosis level was equivalent to the sum of the levels seen in the individual cultures: MDA-MB-231 alone plus $\mathrm{M} \phi$ alone (Figure 4A and $4 \mathrm{~B}$ ). These results indicate that $\mathrm{TM}$ does not act by "reversing" the $\mathrm{M} \phi$ phenotype (M2 to M1), 
Table 1 Modifications of chemokines induced by coculturing $M \phi$ with MDA-MB-231 cells

\begin{tabular}{|c|c|c|c|c|c|}
\hline \multirow[t]{2}{*}{ Chemokine } & \multicolumn{2}{|c|}{$\begin{array}{l}\text { Expressed } \\
\text { in }\end{array}$} & \multirow[t]{2}{*}{$\begin{array}{l}\text { Overexpressed in } \\
\text { coculture }\end{array}$} & \multirow[t]{2}{*}{ Family } & \multirow[t]{2}{*}{ Function } \\
\hline & $\mathbf{M} \phi$ & MDA & & & \\
\hline $\begin{array}{l}\text { ENA } 78 \\
\text { (CXCL5) }\end{array}$ & - & - & + & $\begin{array}{l}\text { CXC chemokine with } \\
\text { ELR motif }\end{array}$ & $\begin{array}{l}\text { - Pro-angiogenic activity } \\
\text { - Neutrophil chemotaxis } \\
\text { - Monocyte migration }\end{array}$ \\
\hline $\begin{array}{l}\text { GM-CSF } \\
\text { (CSF2) }\end{array}$ & - & + & + & Growth factor & $\begin{array}{l}\text { - Stimulates stem cells to produce granulocytes and monocytes } \\
\text { - Enhances monocytic migration via RhoA and integrin activation, and } \\
\text { via MMP expression }\end{array}$ \\
\hline $\begin{array}{l}\text { GRO }(C X C L 1, \\
2,3)\end{array}$ & + & + & + & $\begin{array}{l}\text { CXC chemokine with } \\
\text { ELR motif }\end{array}$ & $\begin{array}{l}\text { - Angiogenic activity } \\
\text { - Increased migration of PBMC/monocytes }\end{array}$ \\
\hline $\begin{array}{l}\text { GRO } \alpha \\
\text { (CXCL1) }\end{array}$ & - & + & + & $\begin{array}{l}\text { CXC chemokine with } \\
\text { ELR motif }\end{array}$ & $\begin{array}{l}\text { - Angiogenic activity } \\
\text { - Increased migration of PBMC/monocytes }\end{array}$ \\
\hline IL-6 & - & + & + & Inflammatory cytokine & $\begin{array}{l}\text { - Inflammatory cytokine with a well-documented role in cancer } \\
\text { - Recruitment of myelo-monocytes }\end{array}$ \\
\hline IL-8 (CXCL8) & + & + & + & $\begin{array}{l}\text { CXC chemokine with } \\
\text { ELR motif }\end{array}$ & $\begin{array}{l}\text { - Migration of neutrophils } \\
\text { - Important role in tumour growth, angiogenesis, and metastasis }\end{array}$ \\
\hline IL-10 & - & - & + & $\begin{array}{l}\text { - Anti-inflammatory } \\
\text { cytokine }\end{array}$ & - Anti-inflammatory cytokine produced by M2 M $\phi$ \\
\hline $\begin{array}{l}\text { MCP-1 } \\
\text { (CCL2) }\end{array}$ & + & - & + & CC chemokine & - Recruitment of monocytes to sites of injury \\
\hline $\begin{array}{l}\text { MCP-3 } \\
\text { (CCL7) }\end{array}$ & - & - & + & CC chemokine & - Inflammatory cytokine \\
\hline MCSF (CSF1) & - & - & + & Growth factor & $\begin{array}{l}\text { - Facilitates monocyte survival, monocyte-to- M } \phi \text { conversion, M } \phi \\
\text { proliferation, M1 to M2 switch }\end{array}$ \\
\hline MDC (CCL22) & - & - & + & CC chemokine & -Chemotactic for monocytes \\
\hline
\end{tabular}

Table 2 Fold increase in cytokine secretion by coculture of monocytes and MDA-MB-231, as compared to the secretion by the two types of cells cultured separately

\begin{tabular}{|c|c|}
\hline Cytokines & Fold change \\
\hline \multicolumn{2}{|c|}{$\begin{array}{l}\text { Group 1: cytokines secreted by } \mathbf{M} \phi \text { and not by MDA-MB-231: } \\
\text { Ratio coculture medium } / \mathbf{M} \phi \text { medium }\end{array}$} \\
\hline MCP-1 & 1.45 \\
\hline \multicolumn{2}{|c|}{$\begin{array}{l}\text { Group 2: cytokines secreted by MDA-MB-231 and not by } \mathrm{M} \phi \\
\text { Ratio: coculture medium/MDA-MB-231 medium }\end{array}$} \\
\hline GM-CSF & 2.82 \\
\hline Groa & 2.96 \\
\hline IL-6 & 2.68 \\
\hline \multicolumn{2}{|c|}{$\begin{array}{c}\text { Group 3: cytokines secreted by both } \mathrm{M} \phi \text { and MDA-MB-231 } \\
\text { Ratio coculture/(M } \phi \text { medium cultured separately + MDA-MB-231 } \\
\text { medium cultured separately) }\end{array}$} \\
\hline Gro & 1.80 \\
\hline IL-8 & 2.35 \\
\hline \multicolumn{2}{|c|}{ Group 4: cytokines secreted only in the coculture medium } \\
\hline \multicolumn{2}{|l|}{ ENA-78 } \\
\hline \multicolumn{2}{|l|}{$\mathrm{IL}-10$} \\
\hline MCP-3 & \\
\hline
\end{tabular}

In every case, the difference of spot intensity between duplicate determinations was $<10 \%$. The mean of the 4 spots $(2$ membranes $\times 2$ spots per membrane) was used for determining the intensity of expression of each cytokine. consistent with our observation that IL-10 secretion was increased in TM-treated $\mathrm{M} \phi$ (Figure 5).

Finally, we also tested the action of TM on the secretion of cytokines and chemokines that is induced by the cooperation between cancer cells and $\mathrm{M} \phi$. No changes were observed when TM was added during the coculture (Figure 6, comparison between panel A without $\mathrm{TM}$ and panel $\mathrm{B}$ in the presence of TM). The ratio of cytokines secreted in the presence of TM in comparison to its absence did not vary, as the fold change was between 0.85 and 1.15 .

\section{Discussion}

$\mathrm{M} \phi$ constitute the most abundant immune cell population present in the tumour microenvironment [1]. In many cancers, including breast cancers, it is now widely accepted that the presence of $\mathrm{M} \phi$ is associated with a poor prognosis. An increase in angiogenesis has been considered to be one of the major causes of the deleterious effect of $\mathrm{M} \phi$ in tumours. For example, the density of blood microvessels correlates with the extent of $\mathrm{M} \phi$ infiltration in breast cancer [11]; hence we hypothesized that there was a cooperation between $\mathrm{M} \phi$ and cancer cells to induce this angiogenic process. We therefore developed a model which mimics this cooperation by 
culturing $\mathrm{M} \phi$ in vitro with the aggressive breast cancer cells MDA-MB-231, analysed the consequences of this cooperation, and investigated the molecular mechanism mediating this angiogenic pathway. The $\mathrm{M} \phi$ population we tested was derived from blood monocytes and thus, at least theoretically, might be anticipated to contain some dendritic cells as well. Although we do not formally exclude this possibility, our protocol for $\mathrm{M} \phi$ preparation does not favour differentiation into dendritic cells. Indeed, neither the classical stimuli for dendritic cell differentiation (IL4 plus GM-CSF [32,33]) nor more recently reported contributory agents (IFN $\alpha$, TNF $\alpha$, IL15, thymic stromal lymphopoietin, Toll-like receptor ligands [34]) were present during the 7-day culture period used to prepare $\mathrm{M} \phi$ for testing. Removal of nonadherent cells during $\mathrm{M} \phi$ generation further disfavours dendritic cell differentiation, given that immature dendritic cells have been shown to be nonadherent cells [35]. Moreover, MDA-MB-231 cells secrete IL-6 (Table 1 ), which is known to switch the differentiation of monocytes from dendritic cells to $\mathrm{M} \phi$ [36].

We found that the coculture medium induced greater angiogenic activity than did the culture medium of either $\mathrm{M} \phi$ or MDA-MB-231 alone in the CAM model; this enhanced angiogenic activity was evidenced by the formation of a secondary capillary network in the CAM with increases in both total number of capillaries and total length of sprouted vessels. The increased angiogenesis was still seen when coculture medium was diluted 1:2 in order to normalize for the number of cells participating in the secretion of angiogenic factors (not shown).

Next, we confirmed that the coculture of $\mathrm{M} \phi$ with MDA-MB-231 cells induced a switch of M1 M $\phi$ to an M2 phenotype as shown 1) by the great reduction of CD80 expression under stimulating conditions using LPS and IFN $\gamma$ on CD14 positive cells $(\mathrm{M} \phi)$ - the fact that LPS markedly potentiated the expression of CD80 by $\mathrm{M} \phi$ has also been observed by Foss et al. [37], 2) by the reduction of TNF $\alpha$ secretion by LPS + IFN $\gamma$ activated $\mathrm{M} \phi$, suggestive of a reduction in the number of M1 M $\phi$ during the coculture, and 3) by the increased secretion of IL-10 into the coculture medium, pointing to a switch toward an M2 phenotype. Interestingly, this switch occurred despite the fact that, as shown by the antibody cytokine array, MDA-MB-231 cultured alone produce IL-6, which is an inflammatory cytokine (Figure 4). The M2 phenotype in our model was also characterized by its functional properties: a weak killing activity, and an increase in angiogenesis in the CAM model.

Our results are in good agreement with a number of studies showing that TAMs, which exhibit a predominantly M2-like phenotype [7], can elicit increased angiogenic activity. However, the molecular mechanism responsible for this angiogenic activity was not totally elucidated. To address the molecular mechanism of the angiogenesis pathway, we investigated the production of pro-inflammatory chemokines and cytokines in cocultures of MDA-MB-231 cells and $\mathrm{M} \phi$, in comparison to the secretion by MDA-MB-231 or M $\phi$ cultured separately. Our data (Figure 6 and Table 1) show that the coculture medium contains a number of potent angiogenic factors, as detected by a cytokine-antibodies array. Among the cytokines that are secreted in large amounts into the coculture medium in comparison with the culture medium of resting $\mathrm{M} \phi$ or of MDA-MB-231, we observed a great increase in CXC chemokines with the three amino acids (Glu-Leu-Arg/ELR) immediately amino-terminal to the CXC motif $\left(\mathrm{ELR}^{+}\right)$, which are known to be pro-angiogenic [38]. In particular, an important secretion of the GRO chemokines CXCL1/ GRO $\alpha$, CXCL2/GRO $\beta$, CXCL3/GRO $\gamma$, as well as CXCL5/ENA-78 and CXCL8/IL-8 was noted. All these chemokines play a significant role in mediating angiogenic activity during tumourigenesis in a variety of cancers [39-44] and have been shown to be of great importance in tumour progression [45,46].

Interestingly, in addition to their angiogenic activity, it has been reported that these chemokines also play a role in monocyte recruitment in inflammation, since the blood monocytes express chemokine receptors, including CXCR2. Besides other functions, the interactions of these receptors with their chemokines induce monocyte arrest and transmigration through the endothelium, which is one of the earliest steps in monocyte recruitment, thereby efficiently regulating inflammation [47]. Therefore our data are suggestive of an autocrine loop, because these chemokines are secreted by $\mathrm{M} \phi$ in cooperation with cancer cells, and they also participate in monocyte recruitment.

In addition, ENA-78 was reported to be an attractant for neutrophils [48], which can also be involved in tumour growth and metastasis [49].

An increase in the proinflammatory cytokine IL-6 was also observed in the coculture medium, whereas a decrease in the secretion of this cytokine would have been expected due to the M2 phenotype of the $\mathrm{M} \phi$ in the coculture. This can be explained by the observation of a constitutive secretion of IL- 6 by the MDA-MB-231 cells, which could be responsible for an autocrine loop for IL-6 secretion, as has been proposed for colon cancer [50]. In other words, the observed increase in IL-6 secretion in the cocultures may be produced by the cancer cells themselves.

Our antibody array data also indicated an increase in M-CSF concentration in the coculture medium in comparison to the conditioned media from both $\mathrm{M} \phi$ alone and MDA-MB-231 alone. This increased secretion could 
elicit neovascularisation in breast cancer $[5,12]$ and could also contribute to the M1 to M2 switch, since MCSF-treated monocytes express a substantial part of the M2 transcriptome [51].

We next investigated the effect of TM on the angiogenesis induced by the cooperation between $\mathrm{M} \phi$ and the MDA-MB-231 cancer cells. Several studies emphasize that TM reduces the angiogenic activity induced by tumours [52-58], which is why TM has been proposed in the therapy of cancers. However, the effect of TM has not previously been tested when cancer cells are incubated with $\mathrm{M} \phi$, which represents a more physiological context: cancer associated with inflammation. We firstly demonstrated that the action of TM cannot be explained by a reversion of the angiogenic $\mathrm{M} \phi$ phenotype (M2 to M1), since CD80 was not detected on cells cultured in presence of TM. We also determined that the addition of TM led to a reduction of LPS/IFN $\gamma$ induced TNF $\alpha$ secretion (decrease of more than 80\%) and an increase of IL-10 secretion in cocultured cells, and did not increase the apoptotic potential of $\mathrm{M} \phi$. Pan et al. [52] have proposed that TM inhibits angiogenesis through suppression of the NF- $\kappa \mathrm{B}$ signalling cascade. Given that TNF $\alpha$ secretion is NF- $\kappa$ B dependent, our TNF $\alpha$ results (Figure 3) are consistent with this interpretation, and seem to indicate that TM, like the coculture, induces a switch from M1 to M2. They also suggest that defective activation of NF- $\kappa \mathrm{B}$ could lead to an M2 phenotype.

Finally, we show that, in our model, TM, which inhibits the angiogenic activity of the coculture medium, does not modify the secretion of cytokines and chemokines that is induced by the coculture. Therefore, we rather propose that TM blocks the cell signalling induced by the action of angiogenic chemokines on endothelial cells. This would be in good agreement with the studies of Donate et al. [26] and Juarez et al. [59], who showed that TM attenuates angiogenesis through the inhibition of superoxide dismutase.

\section{Conclusions}

In summary, based on the results and rationale presented here, we conclude that the cooperation between $\mathrm{M} \phi$ and the aggressive breast cancer cells MDAMB-231 transformed M1 M $\phi$ to an angiogenic, M2 phenotype. This coculture-induced increase in angiogenic activity, attested by an increased secretion of CXC chemokines, was found to be inhibited by TM. However, TM did not modify the cytokine secretion profile, which suggests that the TM-mediated anti-angiogenic activity may be due to defective cell signalling by these angiogenic chemokines at the level of their endothelial cell targets.

\section{List of abbreviations used}

bFGF: basic Fibroblast Growth Factor; CAM: chick chorioallantoic membrane; CK: cytokeratin; DNA: Deoxy-Ribonucleic Acid; EGF: Epidermal Growth Factor; ELISA: Enzyme-Linked Immunosorbent Assay; ENA-78: Epithelial NeutrophilActivating peptide 78; FCS: foetal calf serum; GCSF: Granulocyte ColonyStimulating Factor; GM-CSF: Granulocyte-Macrophage Colony Stimulating Factor; GRO: Growth Related Oncogene; HIF: Hypoxia-inducible Factor; IGF-I: Insulin-like Growth Factor-I; IL: interleukin; IFN $\gamma$ : interferon $\gamma_{;}$LPS:

lipopolysaccharide; M $\phi$ : macrophage; MCP-1: Monocyte Chemotactic Protein1; MCSF: Macrophage Colony Stimulating Factor; MDC: Macrophage-Derived Chemokine; MIG: Monokine induced by IFN $\gamma$; MIP-1 $\alpha$ : Macrophage Inflammatory Protein-1 $\alpha$; NF- $\kappa$ B: nuclear factor kappa-light-chain-enhancer of activated B cells; PBS: phosphate-buffered saline; PDGF BB: Platelet-Derived Growth Factor-BB; RANTES: Regulated on Activation Normal T cell Expressed and Secreted; SCF: human Stem Cell Factor; SDF-1: Stromal-Derived Factor-1; SEM: standard error of the mean; TAM: Tumour-Associated Macrophages; TARC: Thymus and Activation-Regulated Chemokine; TGF- $\beta$ 1: Transforming Growth Factor- $\beta$ 1; TM: tetrathiomolybdate; TNF $\alpha$ : Tumour Necrosis Factor $\alpha$; VEGF: Vascular Endothelial Growth Factor.

\section{Acknowledgements}

We are grateful to the comité de l'Eure de la Ligue contre le Cancer and to the Association Ti'toine, for financing the fellowship of Ulrich Joimel. We thank the Groupement des Entreprises Francaises dans la Lutte contre le Cancer (GEFLUC) Rouen Normandie and the comité de Seine-Maritime de la Ligue contre le Cancer, who generously supported this work by a program grant from the Cancer Research Campaign.

\section{Author details}

'Laboratoire M.E.R.C.I - EA 3829, Faculté de Médecine et de Pharmacie, Université de Rouen, 22 Bd Gambetta, 76183 Rouen cedex, France. ${ }^{2}$ Service et Laboratoire d'Oncologie Médicale de L'Hôtel Dieu de Paris, Paris, France. ${ }^{3}$ UMRS 872 INSERM, Université Pierre et Marie Curie-Paris 6 and Université Paris Descartes, Equipe 18, Centre de Recherche des Cordeliers, Paris, France. ${ }^{4}$ Université Paris-Sud and CNRS FRE 3239, IAL, 7 rue Guy Moquet, BP8, 94801 Villejuif Cedex, France. ${ }^{5}$ Université Paris Descartes, Hôpital Hôtel-Dieu, AP-HP Paris, France.

\section{Authors' contributions}

UJ was responsible for this study, designing and executing experiments, interpreting the results and contributing to drafting the manuscript. CG participated in the analysis and interpretation of the results, was involved in writing the manuscript and provided assistance to UJ for the experiments. JS participated in study development and critically reviewed the data, contributing to interpretation of the results and writing the manuscript. LLP contributed to analysis and interpretation of the results and was extensively involved in writing the manuscript.

JA was involved in drafting the manuscript and revising it for important intellectual content.

$M L$ provided assistance to $U J$ for the experiments.

EB participated in the design of this study, in analysis and interpretation of the results, and in development of the study methods.

LC, JPV and RV provided general intellectual support and participated in data discussions.

$\mathrm{HL}$ and CS were responsible for this study, participating in its design and development, analyzing and interpreting the results, drafting the manuscript and coordinating and overseeing all stages of revision of the manuscript. All authors read and approved the manuscript.

\section{Competing interests}

The authors declare that they have no competing interests.

Received: 7 October 2009 Accepted: 17 July 2010

Published: 17 July 2010

\section{References}

1. Mantovani A, Schioppa T, Porta C, Allavena P, Sica A: Role of tumorassociated macrophages in tumor progression and invasion. Cancer Metastasis Rev 2006, 25(3):315-322. 
2. Gottfried E, Faust S, Fritsche J, Kunz-Schughart LA, Andreesen R, Miyake K, Kreutz M: Identification of genes expressed in tumor-associated macrophages. Immunobiology 2003, 207(5):351-359.

3. Bailey C, Negus R, Morris A, Ziprin P, Goldin R, Allavena P, Peck D, Darzi A: Chemokine expression is associated with the accumulation of tumour associated macrophages (TAMs) and progression in human colorectal cancer. Clin Exp Metastasis 2007, 24(2):121-130.

4. Lin EY, Nguyen AV, Russell RG, Pollard JW: Colony-stimulating factor 1 promotes progression of mammary tumors to malignancy. J Exp Med 2001, 193(6):727-740

5. Saji H, Koike M, Yamori T, Saji S, Seiki M, Matsushima K, Toi M: Significant correlation of monocyte chemoattractant protein-1 expression with neovascularization and progression of breast carcinoma. Cancer 2001, 92(5):1085-1091.

6. Brigati C, Noonan DM, Albini A, Benelli R: Tumors and inflammatory infiltrates: friends or foes? Clin Exp Metastasis 2002, 19(3):247-258,

7. Mantovani A, Sozzani S, Locati M, Allavena P, Sica A: Macrophage polarization: tumor-associated macrophages as a paradigm for polarized M2 mononuclear phagocytes. Trends Immunol 2002, 23(11):549-555.

8. Luo Y, Zhou H, Krueger J, Kaplan C, Lee SH, Dolman C, Markowitz D, Wu W, Liu C, Reisfeld RA, et al: Targeting tumor-associated macrophages as a novel strategy against breast cancer. J Clin Invest 2006, 116(8):2132-2141.

9. Sica A, Schioppa T, Mantovani A, Allavena P: Tumour-associated macrophages are a distinct M2 polarised population promoting tumour progression: potential targets of anti-cancer therapy. Eur J Cancer 2006, 42(6):717-727.

10. Welm AL, Sneddon JB, Taylor C, Nuyten DS, van de Vijver MJ, Hasegawa BH, Bishop JM: The macrophage-stimulating protein pathway promotes metastasis in a mouse model for breast cancer and predicts poor prognosis in humans. Proc Natl Acad Sci USA 2007, 104(18):7570-7575.

11. Lin EY, Li JF, Gnatovskiy L, Deng Y, Zhu L, Grzesik DA, Qian H, Xue XN, Pollard JW: Macrophages regulate the angiogenic switch in a mouse model of breast cancer. Cancer Res 2006, 66(23):11238-11246.

12. Ueno T, Toi M, Saji H, Muta M, Bando H, Kuroi K, Koike M, Inadera $H$, Matsushima K: Significance of macrophage chemoattractant protein-1 in macrophage recruitment, angiogenesis, and survival in human breast cancer. Clin Cancer Res 2000, 6(8):3282-3289.

13. Colpaert CG, Vermeulen PB, Benoy I, Soubry A, van Roy F, van Beest $P$, Goovaerts G, Dirix LY, van Dam P, Fox SB, et al: Inflammatory breast cancer shows angiogenesis with high endothelial proliferation rate and strong E-cadherin expression. Br J Cancer 2003, 88(5):718-725.

14. Tsutsui S, Yasuda K, Suzuki K, Tahara K, Higashi H, Era S: Macrophage infiltration and its prognostic implications in breast cancer: the relationship with VEGF expression and microvessel density. Oncol Rep 2005, 14(2):425-431.

15. Leek RD, Lewis CE, Whitehouse R, Greenall M, Clarke J, Harris AL: Association of macrophage infiltration with angiogenesis and prognosis in invasive breast carcinoma. Cancer Res 1996, 56(20):4625-4629.

16. Torisu $\mathrm{H}$, Ono M, Kiryu H, Furue M, Ohmoto Y, Nakayama J, Nishioka Y, Sone S, Kuwano M: Macrophage infiltration correlates with tumor stage and angiogenesis in human malignant melanoma: possible involvement of TNFalpha and IL-1alpha. Int J Cancer 2000, 85(2):182-188.

17. Blot E, Chen W, Vasse M, Paysant J, Denoyelle C, Pille JY, Vincent L, Vannier JP, Soria J, Soria C: Cooperation between monocytes and breast cancer cells promotes factors involved in cancer aggressiveness. $\mathrm{Br} J$ Cancer 2003, 88(8):1207-1212.

18. Gordon S: Alternative activation of macrophages. Nat Rev Immunol 2003, 3(1):23-35.

19. Martinez FO, Sica A, Mantovani A, Locati M: Macrophage activation and polarization. Front Biosci 2008, 13:453-461

20. Hagemann T, Wilson J, Kulbe H, Li NF, Leinster DA, Charles K, Klemm F, Pukrop T, Binder C, Balkwill FR: Macrophages induce invasiveness of epithelial cancer cells via NF-kappa B and JNK. J Immunol 2005, 175(2):1197-1205.

21. Hagemann T, Lawrence T, McNeish I, Charles KA, Kulbe H, Thompson RG, Robinson SC, Balkwill FR: "Re-educating" tumor-associated macrophages by targeting NF-kappaB. J Exp Med 2008, 205(6):1261-1268.

22. Greten FR, Eckmann L, Greten TF, Park JM, Li ZW, Egan LJ, Kagnoff MF, Karin M: IKKbeta links inflammation and tumorigenesis in a mouse model of colitis-associated cancer. Cell 2004, 118(3):285-296.
23. Saccani A, Schioppa T, Porta C, Biswas SK, Nebuloni M, Vago L, Bottazzi B, Colombo MP, Mantovani A, Sica A: p50 nuclear factor-kappaB overexpression in tumor-associated macrophages inhibits $\mathrm{M} 1$ inflammatory responses and antitumor resistance. Cancer Res 2006, 66(23): 11432-11440.

24. Bohuslav J, Kravchenko W, Parry GC, Erlich JH, Gerondakis S, Mackman N, Ulevitch RJ: Regulation of an essential innate immune response by the p50 subunit of NF-kappaB. J Clin Invest 1998, 102(9):1645-1652.

25. Pass HI, Brewer GJ, Dick R, Carbone M, Meraiver S: A phase II trial of tetrathiomolybdate after surgery for malignant mesothelioma: final results. Ann Thorac Surg 2008, 86(2):383-389; discussion 390.

26. Donate F, Juarez JC, Burnett ME, Manuia MM, Guan X, Shaw DE, Smith EL, Timucin C, Braunstein MJ, Batuman OA, et al: Identification of biomarkers for the antiangiogenic and antitumour activity of the superoxide dismutase 1 (SOD1) inhibitor tetrathiomolybdate (ATN-224). Br J Cancer 2008, 98(4):776-783.

27. Brewer GJ: Copper lowering therapy with tetrathiomolybdate as an antiangiogenic strategy in cancer. Curr Cancer Drug Targets 2005, 5(3):195-202.

28. Von Knethen AA, Brune B: Delayed activation of PPARgamma by LPS and IFN-gamma attenuates the oxidative burst in macrophages. FASEB $J$ 2001, 15(2):535-544.

29. Helinski EH, Bielat $\mathrm{KL}$, Ovak GM, Pauly JL: Long-term cultivation of functional human macrophages in Teflon dishes with serum-free media. J Leukoc Biol 1988, 44(2):111-121.

30. Ribatti D, Gualandris A, Bastaki M, Vacca A, lurlaro M, Roncali L, Presta M New model for the study of angiogenesis and antiangiogenesis in the chick embryo chorioallantoic membrane: the gelatin sponge/ chorioallantoic membrane assay. J Vasc Res 1997, 34(6):455-463.

31. Badylak SF, Valentin JE, Ravindra AK, McCabe GP, Stewart-Akers AM: Macrophage phenotype as a determinant of biologic scaffold remodeling. Tissue Eng Part A 2008, 14(11):1835-1842.

32. Romani N, Gruner S, Brang D, Kampgen E, Lenz A, Trockenbacher B, Konwalinka G, Fritsch PO, Steinman RM, Schuler G: Proliferating dendritic cell progenitors in human blood. J Exp Med 1994, 180(1):83-93.

33. Sallusto F, Lanzavecchia A: Efficient presentation of soluble antigen by cultured human dendritic cells is maintained by granulocyte/ macrophage colony-stimulating factor plus interleukin 4 and downregulated by tumor necrosis factor alpha. J Exp Med 1994 179(4):1109-1118.

34. Jacobs B, Wuttke M, Papewalis C, Seissler J, Schott M: Dendritic cell subtypes and in vitro generation of dendritic cells. Horm Metab Res 2008, 40(2):99-107.

35. Romani N, Reider D, Heuer M, Ebner S, Kampgen E, Eibl B, Niederwieser D, Schuler $\mathrm{G}$ : Generation of mature dendritic cells from human blood. An improved method with special regard to clinical applicability. I Immunol Methods 1996, 196(2):137-151.

36. Chomarat P, Banchereau J, Davoust J, Palucka AK: IL-6 switches the differentiation of monocytes from dendritic cells to macrophages. Nat Immunol 2000, 1(6):510-514.

37. Foss DL, Zilliox MJ, Murtaugh MP: Differential regulation of macrophage interleukin-1 (IL-1), IL-12, and CD80-CD86 by two bacterial toxins. Infect Immun 1999, 67(10):5275-5281.

38. Strieter RM, Polverini PJ, Kunkel SL, Arenberg DA, Burdick MD, Kasper J, Dzuiba J, Van Damme J, Walz A, Marriott D, et al: The functional role of the ELR motif in CXC chemokine-mediated angiogenesis. J Biol Chem 1995, 270(45):27348-27357.

39. Arenberg DA, Kunkel SL, Polverini PJ, Glass M, Burdick MD, Strieter RM: Inhibition of interleukin-8 reduces tumorigenesis of human non-small cell lung cancer in SCID mice. J Clin Invest 1996, 97(12):2792-2802.

40. Arenberg DA, Polverini PJ, Kunkel SL, Shanafelt A, Hesselgesser J, Horuk R, Strieter RM: The role of CXC chemokines in the regulation of angiogenesis in non-small cell lung cancer. J Leukoc Biol 1997, 62(5):554-562.

41. Arenberg DA, Keane MP, DiGiovine B, Kunkel SL, Morris SB, Xue YY, Burdick MD, Glass MC, lannettoni MD, Strieter RM: Epithelial-neutrophil activating peptide (ENA-78) is an important angiogenic factor in nonsmall cell lung cancer. J Clin Invest 1998, 102(3):465-472.

42. Arenberg DA, Keane MP, DiGiovine B, Kunkel SL, Strom SR, Burdick MD, lannettoni MD, Strieter RM: Macrophage infiltration in human non-small- 
cell lung cancer: the role of $\mathrm{CC}$ chemokines. Cancer Immunol Immunother 2000, 49(2):63-70.

43. Haghnegahdar H, Du J, Wang D, Strieter RM, Burdick MD, Nanney LB, Cardwell N, Luan J, Shattuck-Brandt R, Richmond A: The tumorigenic and angiogenic effects of MGSA/GRO proteins in melanoma. J Leukoc Biol 2000, 67(1):53-62.

44. Keane MP, Belperio JA, Xue YY, Burdick MD, Strieter RM: Depletion of CXCR2 inhibits tumor growth and angiogenesis in a murine model of lung cancer. J Immunol 2004, 172(5):2853-2860.

45. Strieter RM, Polverini PJ, Arenberg DA, Walz A, Opdenakker G, Van Damme J, Kunkel SL: Role of C-X-C chemokines as regulators of angiogenesis in lung cancer. J Leukoc Biol 1995, 57(5):752-762.

46. Strieter RM, Burdick MD, Mestas J, Gomperts B, Keane MP, Belperio JA: Cancer CXC chemokine networks and tumour angiogenesis. Eur I Cancer 2006, 42(6):768-778.

47. Smith DF, Galkina E, Ley K, Huo Y: GRO family chemokines are specialized for monocyte arrest from flow. Am J Physiol Heart Circ Physiol 2005, 289: (5):H1976-1984.

48. Lukacs NW, Hogaboam CM, Kunkel SL, Chensue SW, Burdick MD, Evanoff HL, Strieter RM: Mast cells produce ENA-78, which can function as a potent neutrophil chemoattractant during allergic airway inflammation. J Leukoc Biol 1998, 63(6):746-751.

49. Remedi MM, Donadio AC, Chiabrando GA: Polymorphonuclear cells stimulate the migration and metastatic potential of rat sarcoma cells. Int $J$ Exp Pathol 2009, 90(1):44-51.

50. Li YY, Hsieh LL, Tang RP, Liao SK, Yeh KY: Interleukin-6 (IL-6) released by macrophages induces IL-6 secretion in the human colon cancer HT-29 cell line. Hum Immunol 2009, 70(3):151-158.

51. Martinez FO, Gordon S, Locati M, Mantovani A: Transcriptional profiling of the human monocyte-to-macrophage differentiation and polarization: new molecules and patterns of gene expression. J Immunol 2006, 177(10):7303-7311.

52. Pan Q, Bao LW, Merajver SD: Tetrathiomolybdate inhibits angiogenesis and metastasis through suppression of the NFkappaB signaling cascade. Mol Cancer Res 2003, 1(10):701-706.

53. Sproull M, Brechbiel M, Camphausen $\mathrm{K}$ : Antiangiogenic therapy through copper chelation. Expert Opin Ther Targets 2003, 7(3):405-409.

54. Brewer GJ, Merajver SD: Cancer therapy with tetrathiomolybdate: antiangiogenesis by lowering body copper-a review. Integr Cancer Ther 2002, 1(4):327-337.

55. Goodman VL, Brewer GJ, Merajver SD: Copper deficiency as an anti-cancer strategy. Endocr Relat Cancer 2004, 11(2):255-263.

56. Lowndes $\mathrm{SA}$, Harris AL: The role of copper in tumour angiogenesis. J Mammary Gland Biol Neoplasia 2005, 10(4):299-310.

57. Hassouneh B, Islam M, Nagel T, Pan Q, Merajver SD, Teknos TN: Tetrathiomolybdate promotes tumor necrosis and prevents distant metastases by suppressing angiogenesis in head and neck cancer. $\mathrm{Mol}$ Cancer Ther 2007, 6(3):1039-1045.

58. Carpenter A, Rassam A, Jennings MH, Robinson-Jackson S, Alexander JS, Erkuran-Yilmaz C: Effects of ammonium tetrathiomolybdate, an oncolytic/ angiolytic drug on the viability and proliferation of endothelial and tumor cells. Inflamm Res 2007, 56(12):515-519.

59. Juarez JC, Betancourt O, Pirie-Shepherd SR, Guan X, Price ML, Shaw DE, Mazar AP, Donate F: Copper binding by tetrathiomolybdate attenuates angiogenesis and tumor cell proliferation through the inhibition of superoxide dismutase 1. Clin Cancer Res 2006, 12(16):4974-4982.

\section{Pre-publication history}

The pre-publication history for this paper can be accessed here: http://www.biomedcentral.com/1471-2407/10/375/prepub

doi:10.1186/1471-2407-10-375

Cite this article as: Joimel et al: Stimulation of angiogenesis resulting from cooperation between macrophages and MDA-MB-231 breast cancer cells: proposed molecular mechanism and effect of tetrathiomolybdate. BMC Cancer 2010 10:375.

\section{Submit your next manuscript to BioMed Central and take full advantage of:}

- Convenient online submission

- Thorough peer review

- No space constraints or color figure charges

- Immediate publication on acceptance

- Inclusion in PubMed, CAS, Scopus and Google Scholar

- Research which is freely available for redistribution

Submit your manuscript at www.biomedcentral.com/submit
Biomed Central 